\title{
Elemental geochemistry and paleoenvironment reconstruction of Upper Paleozoic in northeastern Ordos Basin, China
}

\author{
DR. YONG LI, PH.D
}

China University of Mining and Technology, Beijing

Presenting Author: liyong@cumtb.edu.cn

A combination interpretation of the depositional environment, provenance, and paleoclimate contains crucial information about understanding the formation and distribution petroleum systems. The trace elements, rare earth elements (REEs) and minerals distribution concentrations in 100 mudstone cores from the entire Upper Paleozoic section (Carboniferous Benxi and Taiyuan formations; Permian Shanxi, Xiashihezi, Shangshihezi, and Shiqianfeng formations) in the Linxing area of the northeastern Ordos Basin were determined. The results show that the study area has clear light REE enrichment, but the degree of enrichment is generally poor. The Ce content is basically normal or has a slightly negative anomaly, and the Eu has a negative "V" type anomaly. Redox proxies $(\mathrm{V} / \mathrm{Ni}, \mathrm{V} /(\mathrm{V}+\mathrm{Ni})$, and $\delta \mathrm{Ce})$ indicate that most of the samples were deposited in relatively dysoxic/oxic conditions. A warm and humid climate (represented by the $\mathrm{Sr} / \mathrm{Cu}$ and $\mathrm{Rb} / \mathrm{Sr}$ ratios) prevailed during the Benxi to Xiashihezi periods, even though extremely dry climate occurred in the Benxi and Taiyuan periods. The Shiqianfeng period has been into a completely dry climate. The La-Th-Sc and Th-Co$\mathrm{Zr} / 10$ diagrams indicate that the samples were deposited in an active continental margin and passive margin. A few samples from the Benxi and Taiyuan formations from the continental island arc. The discriminant diagrams of $\Sigma \mathrm{REE}$ vs $\mathrm{La} / \mathrm{Yb}$ reveals that the provenance consists mainly of sedimentary rocks and certain alkaline basalt and/or granite areas, whereas the Shiqianfeng Formation was only influenced by sedimentary rocks. The increase in $\Sigma$ REE concentrations and the decrease in the $\mathrm{Sr} / \mathrm{Ba}$ ratios above the Benxi Formation indicate a quick increase in terrigenous clast and sea level drop, which is related to Permian tectonic movement. Bivariate plot diagrams (Hf vs $\mathrm{La} / \mathrm{Th}$, and $\mathrm{La} / \mathrm{Sc}$ vs $\mathrm{Co} / \mathrm{Th}$ ) show mixed felsic/basic source influences for all the formations, with the Shanxi Formation displaying certain influences from acidic sources. A comprehensive REE analysis shows that the provenance of the Linxing area is from the Alashan-Yinshan paleocontinent to the north of the Ordos Basin, with the two main invading fluvial directions being recognizable. The results are helpful to predict sandstone distribution and the optimal reservoir selection. 